\title{
Preface to Volume 27(1)
}

Since the last issue, the management of ORiON underwent a restructuring. Jan van Vuuren was elected as vice president, and thus president to be, of the Operations Research Society of South Africa (ORSSA). Due to this new responsibility he had to step down as editor-in-chief of ORiON. I would like to thank Jan van Vuuren for the significant time and effort that was dedicated to ORiON during his term as editor-in-chief. Having worked with Jan in the management team of ORiON over the past seven years was a rewarding experience. Fortunately, Jan's expertise will not be lost to ORiON, as he has accepted an invitation to stay on as an associate editor of ORiON. Thank you, Jan, for a job well done. I would like to wish Jan all of the best in his new role as vice present, and later as president, of ORSSA.

Another result of the restructuring is that the role of business manager changed to that of journal manager. In future this position will be filled by Martin Kidd from the Department of Logistics at Stellenbosch University. Martin has already served ORiON for a couple of years in the role of editorial assistant and is thus well acquainted with the processes at ORiON. Martin is doing a sterling job at handling almost all ORiON's administrative duties.

Anton de Villiers, also from the Department of Logistics at Stellenbosch University, will remain part of the ORiON team in his role as typesetting assistant. He is performing an excellent (and time consuming) job at typesetting all manuscripts in $\mathrm{HAT}_{\mathrm{E}} \mathrm{X}$.

I am looking forward to continue working with Martin and Anton on the editorial team of ORiON.

Stephan Visagie

Stellenbosch

June 2011 